\title{
Association between trans fats and \\ cardiovascular risks: a systematic review of the literature
}

\section{Associação entre gorduras trans e riscos cardiovasculares: uma revisão sistemática da literatura}

\author{
Camila Fongaro ${ }^{1}$ \\ Caroline Calloni² \\ Patricia Kelly Wilmsen Dalla Santa Spada ${ }^{3}$
}

\section{ABSTRACT}

Objective: To systematically review the scientific literature relating the effects of trans fatty acids on cardiovascular risk. Methods: A literature search was conducted in the following databases: MEDLINE, LILACS and ScienceDirect in September of 2015. The following descriptors were used: Trans Fat AND Trans Fatty Acids AND Cardiovascular Diseases present in the title, keywords or MeSH Terms and abstract. The included studies were conducted in humans, published in Portuguese, English or Spanish. Studies were excluded for being case study reports, case-control or review articles. Results: There was a positive association between the consumption of trans fatty acids and deleterious changes in risk factors for cardiovascular disease. Conclusion: Given the importance of eating habits on health, it is relevant to note that reducing the trans fat content of foods and of the diet is only one component of a multifaceted strategy to improve nourishment and reduce the risk of chronic diseases related to diet, in particular cardiovascular diseases.

\section{KEYWORDS}

Trans fatty acids; Cardiovascular diseases; Systematic review; Trans fat.

1,2,3 FSG - Centro Universitário da Serra Gaúcha. 


\section{RESUMO}

Objetivo: Sistematicamente revisar a literatura científica, relacionando os efeitos dos ácidos graxos trans com o risco cardiovascular. Métodos: A busca bibliográfica foi feita nas seguintes bases de dados: MEDLINE, LILACS e ScienceDirect em setembro de 2015. Foram utilizados os seguintes descritores: Trans Fat AND Trans Fatty Acids AND Cardiovascular Diseases, presentes no título, palavras-chave ou MeSH Terms e resumo. Foram incluídos estudos conduzidos em humanos, publicados nos idiomas português, inglês ou espanhol. Foram excluídos estudos que reportavam estudo de caso, caso-controle ou artigos de revisão. Resultados: Observouse uma associação positiva entre o consumo de ácidos graxos trans e mudanças desfavoráveis em fatores de risco para doenças cardiovasculares. Conclusão: Dada a importância dos hábitos alimentares sobre a saúde, é relevante observar que a redução do teor de gordura trans de alimentos e da dieta é apenas um componente de uma estratégia multifacetada para melhorar a alimentação e reduzir o risco de doenças crônicas relacionadas com a dieta, em particular doenças cardiovasculares.

\section{PALAVRAS-CHAVE}

Ácidos graxos trans; Doenças cardiovasculares; Revisão sistemática; Gordura trans. 


\section{INTRODUCTION}

Since the 1990s trans fatty acids (TFA) have been associated with adverse effects (MENSINK \& KATAN, 1989, 1990, 1993; MENSINK et al., 1994; ASCHERIO et al., 1994; WILLETT et al., 1993; TAVANI et al., 1997; PIETINEM et al., 1997). It has been observed that they induce an increase in the concentration of low-density lipoprotein (LDL) cholesterol, which is popularly known as "bad cholesterol" due to the fact that its excess can lead to the formation of plaques of fat in the arteries, which can cause atherosclerosis and increased risk of heart disease, among other problems (MENSINK \& KATAN, 1989, 1990; MENSINK et al. 1994; JAVAHERI \& RADER, 2014; SALTER, 2011). TFA also decrease the concentration of high-density lipoprotein (HDL) cholesterol, the so called "good cholesterol" as it assists in the removal of LDL particles from arteries, showing protective effect against cardiovascular diseases (CVD) and atherosclerosis (MENSINK \& KATAN, 1989, 1990; MENSINK et al., 1994; JAVAHERI \& RADER, 2014; SALTER, 2011). In addition to harmful implications on lipid metabolism, TFA also have a myriad of other undesirable cardiometabolic effects, including pro-inflammatory effects and endothelial dysfunction (MOZAFFARIAN, PISCHON et al., 2004; MOZAFFARIAN, RIMM et al., 2004; CALDER, 2015; MICHA \& MOZAFFARIAN, 2009).

The generic term of TFA represents two separate food sources, a natural one (ruminant trans fatty acids; R-TFA) and an industrial counterpart (industrially produced trans fatty acids; IP-TFA). R-TFA and IP-TFA differ widely in their isomer distribution (i.e. the relative distribution of the position of the trans double bond along the carbon chain), as well as its prevalence in food sources. R-TFA are generally present in foods at low levels (up to $8 \%$ of the total fatty acids in milk fat), whereas IP-TFA can reach up to $61 \%$ of the total fatty acids in pastries and bakery products (STENDER et al., 2008; GAYET-BOYER et al., 2014; BROUWER et al., 2010; TRATTNER et al. 2015). The main IP-TFA in the food supply are elaidic acid isomers, and the main derivative of R-TFA is vaccenic acid; both share the characteristic of having at least one double bond in the "trans" rather than the "cis" configuration (CHOWDHURY, JOHN-
SON et al, 2014; SUNDRAM et al., 1997; WANG et al., 2014).

Trans fatty acids are made industrially by partial hydrogenation of vegetable fats and, to a lesser extent, fish oils by heating to about $400{ }^{\circ} \mathrm{C}$ under high pressure and with the addition of catalysts (MARTIN et al., 2007). IP-TFA is used in a variety of food products, particularly margarines, bakery products, and fast food. Trans fatty acids derived from ruminants are made by the bacterial metabolism of polyunsaturated fatty acids (PUFA) in the rumen of ruminants such as cow, goat and sheep, and are therefore present in all of these animal's fats (STENDER et al., 2008; GAYET-BOYER et al., 2014).

Prominent recent opinion articles, informed by systematic reviews of randomized trials (SACKS \& KATAN, 2002; CHOWDHURY, WARNAKULA et al., 2014; HARCOMBE et al., 2015) and prospective cohort studies (CHOWDHURY, JOHNSON et al, 2014; SIRI-TARINO et al., 2010; KIAGE et al., 2014), called for a review of dietary guidelines for intake and a reassessment of the effects of saturated fat on health; during that time public health efforts to remove trans fat from the food supply in many countries have intensified. Over the past decades, food security concerns have expanded from issues of diseases related to food consumption and contaminants such as lead, to include the effects that food ingredients have on chronic diseases such as heart related ones. In this context, trans fatty acids have received attention of the scientific community and political and administrative bodies of the society in general. Recently, the Food and Drug Administration (FDA) has taken steps to further reduce and remove artificial trans fats in processed foods. Countries like Denmark, Austria, Argentina, Hungary, Iceland, Norway, Switzerland and Sweden have similar guidelines that virtually ban trans fats from food. Note the intention disclosed in the European Action Plan on Food and Nutrition 2015-2020 developed by the Regional Commission for Europe of the World Health Organization (WHO, 2015, p. 10), to "develop and implement national policies to ban or virtually eliminate trans fats from the food supply, with a view to making the European Region trans fat-free." Given the negative implications of trans fats this work intends to present a sys- 
tematic review of the literature to evaluate the evidence from studies that demonstrated an association between intake of trans fatty acids and the risk of heart disease.

\section{METHODS}

A systematic literature review was compiled from the databases Medical Literature Analysis and Retrieval System Online (MEDLINE), Literatura Latino-Americana e do Caribe em Ciências da Saúde (LILACS) and ScienceDirect (Elsevier), having the data search occurred in September of 2015. The following descriptors were used: Trans Fat AND Trans Fatty Acids AND Cardiovascular Diseases present in the title, keywords or MeSH Terms and abstract. The included studies were conducted in humans (as long as they were not clinical studies or articles related to nutritional aspects), published in Portuguese, English or Spanish. Studies were excluded for being case study reports, case-control or review articles.

The article selection was performed in three stages. At first, only the titles of the papers were read. We excluded those who certainly did not fit any of the criteria for inclusion in this study. In the second stage, a reading of the abstracts of the studies selected in the first stage was carried out. Again, those who clearly did not fit any of the predetermined criteria for inclusion were rejected. In the third stage, all of the studies that had passed those two steps were fully read for the final selection of which were included in this review.

\section{RESULTS}

Figure 1 shows the searching flowchart. Initially the literature search yielded 394 items. From the search of the descriptors in the title or abstract, there were discarded 172 studies because they were not related to the purpose of this article, resulting in 222 studies. Of these, 156 were excluded for being literature reviews, or also repeated studies in the databases. Of the remaining 64, 54 were excluded for not meeting other inclusion criteria. Thus, 10 articles were analyzed in this review.
Note that all of the studies were conducted in First World countries, which characteristically have strong economies, high industrialization rates, high technological level, and high social indicators such as good quality of life, good income, low levels of illiteracy, good life expectancy, among others. In total thirteen countries were involved, France was part of three studies (VAN DE VIJVER et al., 2000; CHARDIGNY et al., 2008; MALPUECH-BRUGÈRE et al., 2010). Denmark, the United States and Finland two for each (DYERBERG et al., 2004; BENDSEN, STENDER et al., 2011; JUDD et al., 1998; JONES et al., 2014; VAN DE VIJVER et al., 2000; VIRTANEN et al., 2014). Canada, Italy, New Zealand, Spain, Greece, The Netherlands, Iceland, Portugal, Sweden, each were part of one (JONES et al., 2014; SOFI et al., 2009; BENATAR \& STEWART, 2014; VAN DE VIJVER et al., 2000). Most publications occurred in the last decade and only two works precede the XXI century (JUDD et al., 1998; VAN DE VIJVER et al., 2000). A total of $70 \%$ of the studies addressed individuals of both sexes (JUDD et al., 1998; VAN DE VIJVER et al., 2000; CHARDIGNY et al., 2008; SOFI et al., 2009; MALPUECH-BRUGÈRE et al., 2010; BENATAR \& STEWART, 2014; JONES et al., 2014). Of the remaining $30 \%, 20 \%$ were limited to men (DYERBERG et al., 2004; VIRTANEN et al., 2014). Only one study used non adults, the average age was 16 years (SOFI et al., 2009). Two other studies had a mean age below 30 years (CHARDIGNY et al., 2008; MALPUECH-BRUGÈRE et al., 2010). Six articles had an average age above 45 years (JUDD et al., 1998; VAN DE VIJVER et al., 2000; BENDSEN, STENDER et al., 2011; BENATAR \& STEWART, 2014; JONES et al., 2014; VIRTANEN et al., 2014). The combined average of the population of works on adults was 44 years, the average age of the 10 studies was 41 years. The longer intervention period was 16 weeks, the shortest 3 weeks, and most lasted for 4 to 8 weeks (BENDSEN, STENDER et al., 2011; CHARDIGNY et al., 2008).

One study found that increased consumption of dairy products was associated with a small increase in plasma levels of fatty acids and the decrease in consumption was not associated with any change, leading them to conclude that dietary advice to change consumption of dairy foods has a minimal effect on the levels of fatty acids in the plasma (BENATAR 
Figure 1. Flowchart of selection of included studies for the review.

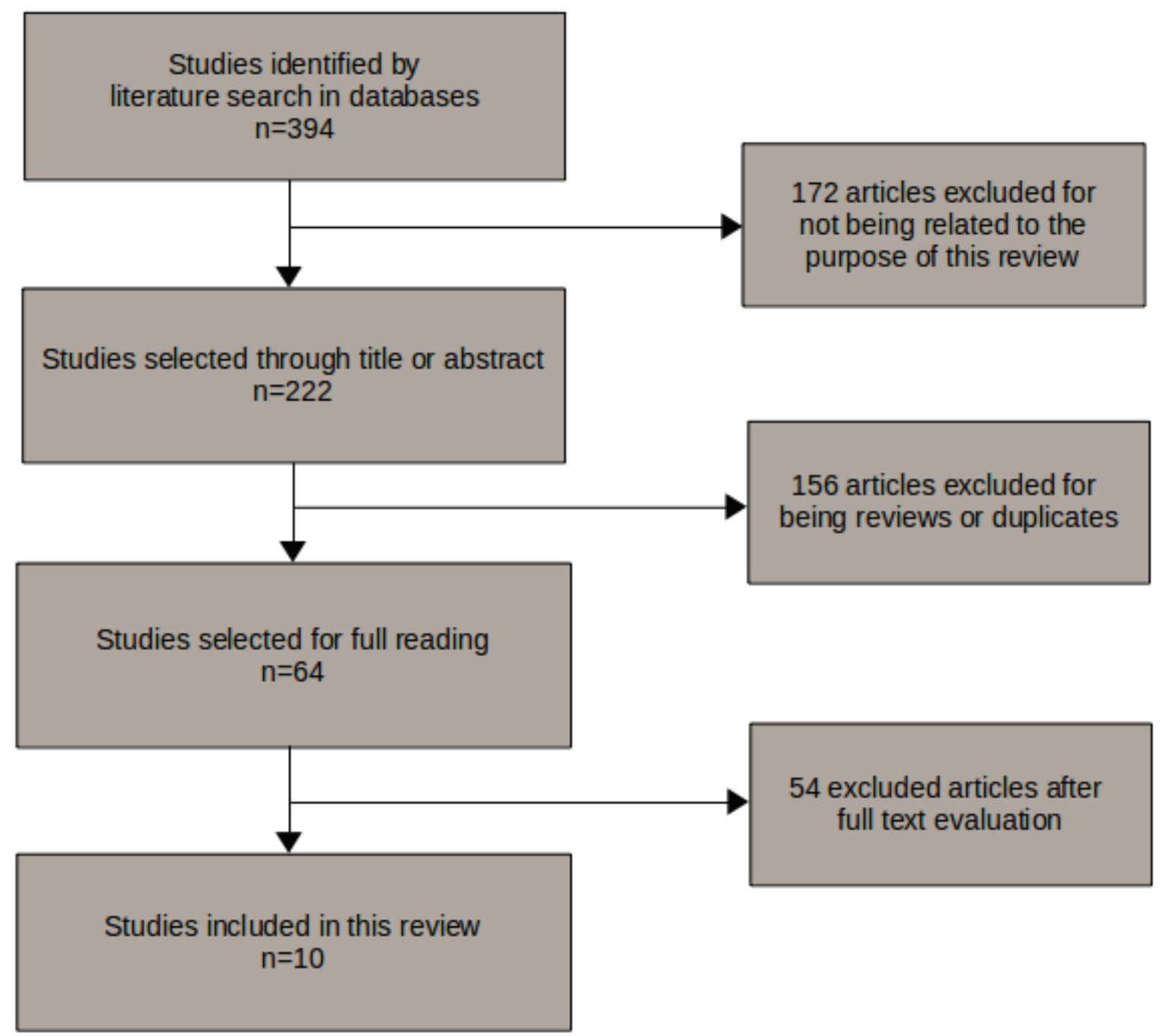

\& STEWART, 2014). Similarly, other researchers found that a limited increase in R-TFA/SFA ratio in dairy products is associated with an improvement in some cardiovascular risk factors (a decrease in total cholesterol, LDL cholesterol, total cholesterol/HDL ratio and $\mathrm{LDL} / \mathrm{HDL}$ ratio). However, a further increase in the proportion of R-TFA/SFA (saturated fatty acids) has no additional benefit (MALPUECH-BRUGÈRE et al., 2010). An experiment concluded that replacing butter, which is high in SFA, for margarine, particularly margarine without TFA and with $49 \%$ of PUFA would be beneficial for the lipid profile (JUDD et al., 1998). Authors found that SFA intake is not an independent risk factor for coronary artery disease, even in a population with higher ranges of SFA intake (VIRTANEN et al., 2014). A study with the participation of 8 European countries concluded that the current levels of consumption of trans fatty acids are not associated with an unfavorable lipid profile (VAN DE VIJVER et al., 2000).

In a dietary intervention lasting eight weeks it was noted a drop in HDL levels in the TFA group and triglycerides in the n-3 PUFA group significantly different from the control group (DYERBERG et al., 2004). Results of a study showed industrially produced sources of TFA in the diet of healthy humans result in plasma concentrations of HDL lower than TFA from natural sources, however the statistical analysis showed that this effect occurred only in women (CHARDIGNY et al., 2008). A trial demonstrated 
that canola oil (6:1:1, n-9:n-6:n-3) supplemented with docosahexaenoic acid (DHA) significantly increased HDL cholesterol and decreased triglycerides while other oils rich in fatty acids $n-6$ and $n-9$ without DHA significantly reduced LDL cholesterol levels (JONES et al., 2014). A study of 16 weeks duration assessed the impact of IP-TFA consumption on systemic inflammation markers in women, finding an increase in plasma levels of tumor necrosis factor (TNF) and its receptors (TNFR-1 and TNFR- 2) (BENDSEN, STENDER et al., 2011). Researchers found that the majority of Italian adolescents showed consumption of TFA above the levels recommended by WHO (SOFI et al., 2009). Table 1 shows some characteristics, such as the country in which the study was conducted, the sample size, the study design, the year of publication and the main results of the analyzed articles.

Table 1. Characteristics of half of the included studies in chronological order of publication.

\section{DISCUSSION}

CVD is the leading cause of death in Brazil, with enormous costs to society, despite hardships in acquiring data, it can be safely estimated that the Brazilian government spends billions, perhaps tens of billions per year with the treatment of CVD (AZAMBUJA et al., 2008; TEICH \& ARAUJO, 2011). The main behavioral risk factors for CVD are diet and smoking, followed by excessive alcohol consumption and physical inactivity (MUNIZ et al., 2012; NISHIDA \& UAUY, 2009). Within diet the key factors include low intake of fruits, vegetables and whole foods and an excessive intake of salt, sugar, SFA and TFA. Of the total calories consumed by the Brazilian population, it is estimated that $52 \%$ are from solid fats and added sugars, which are quite high levels (PEREIRA et al., 2014). WHO recommends that consumption of TFA should be limited to less than $1 \%$ of the total energy intake. The goal of dietary counseling to reduce the consumption of foods with trans and saturated fats is to reduce plasma levels of harmful fats and increase levels of beneficial polyunsaturated fats.

The effect of TFA on CVD risk is mediated through blood lipids and pro- inflammatory processes (WILLETT, 2012; MOZAFFARIAN et al., 2006). Se- veral meta-analyses and systematic reviews have found positive associations between trans fat intake and coronary heart disease (CHD) (HARCOMBE et al., 2015; DE SOUZA et al., 2015; BENDSEN, CHRISTENSEN et al., 2011; FATTORE et al., 2014; GAYET-BOYER et al., 2014; CHOWDHURY, WARNAKULA et al., 2014; DE SOUZA et al., 2015; BENDSEN, CHRISTENSEN et al., 2011; FATTORE et al., 2014). One meta-analysis suggest a $2 \%$ increase in energy from TFA is associated with an increased risk of CHD by $25 \%$ and a $31 \%$ increase in mortality from CHD, these data are consistent with the findings of two previous meta-analyses (DE SOUZA et al., 2015; MOZAFFARIAN et al., 2009; SKEAFF \& MILLER, 2009). In observational studies, high intake of SFA and TFA and low PUFA intake are factors associated with increased cardiovascular risk (MOZAFFARIAN \& CLARKE, 2009). The TFA found in partially hydrogenated oils appears to be more potent than SFA in the development of CHD (TRATTNER et al., 2015). It is suggested that increasing plasma levels of TFA and SFA are associated with an increased risk of CVD. Bearing in mind that trans fatty acids, odd-numbered saturated and polyunsaturated ( $n-3$ and $n-6)$ are not endogenously synthesized, plasma levels reflect intake (WILLETT, 2006, 2012).

Altogether, there is consensus that the high consumption of TFA has negative effects on health (WHO, 2008). The different dietary sources of TFA and its impact on health is what leads to conflicting conclusions. A Norwegian prospective study, including 71,464 men and women, has shown that IP-TFA intake was associated with an increased risk of CHD, and R-TFA intake has been associated with an increased risk of CHD and cardiovascular disease in women, but not in men (LAAKE et al., 2012). In a study performed in rats, trans-vaccenic acid (trans-11 18:1), one of the most frequent natural TFA, was directly associated with CHD and inflammation (WANG et al., 2012). In a case control study including 512 subjects, the relative risk of myocardial infarction was significantly higher for the highest $(5.04 \mathrm{~g} / \mathrm{d})$ versus the lowest $(0.84 \mathrm{~g} / \mathrm{d})$ quintile of energy-adjusted IP-TFA. Energy-adjusted intake of TFA from animal sources was not related to increased risk of myocardial infarction, the lowest quintile was $0.45 \mathrm{~g} / \mathrm{d}$ and the highest $1.79 \mathrm{~g} / \mathrm{d}$ (ASCHERIO et al., 1994). In 


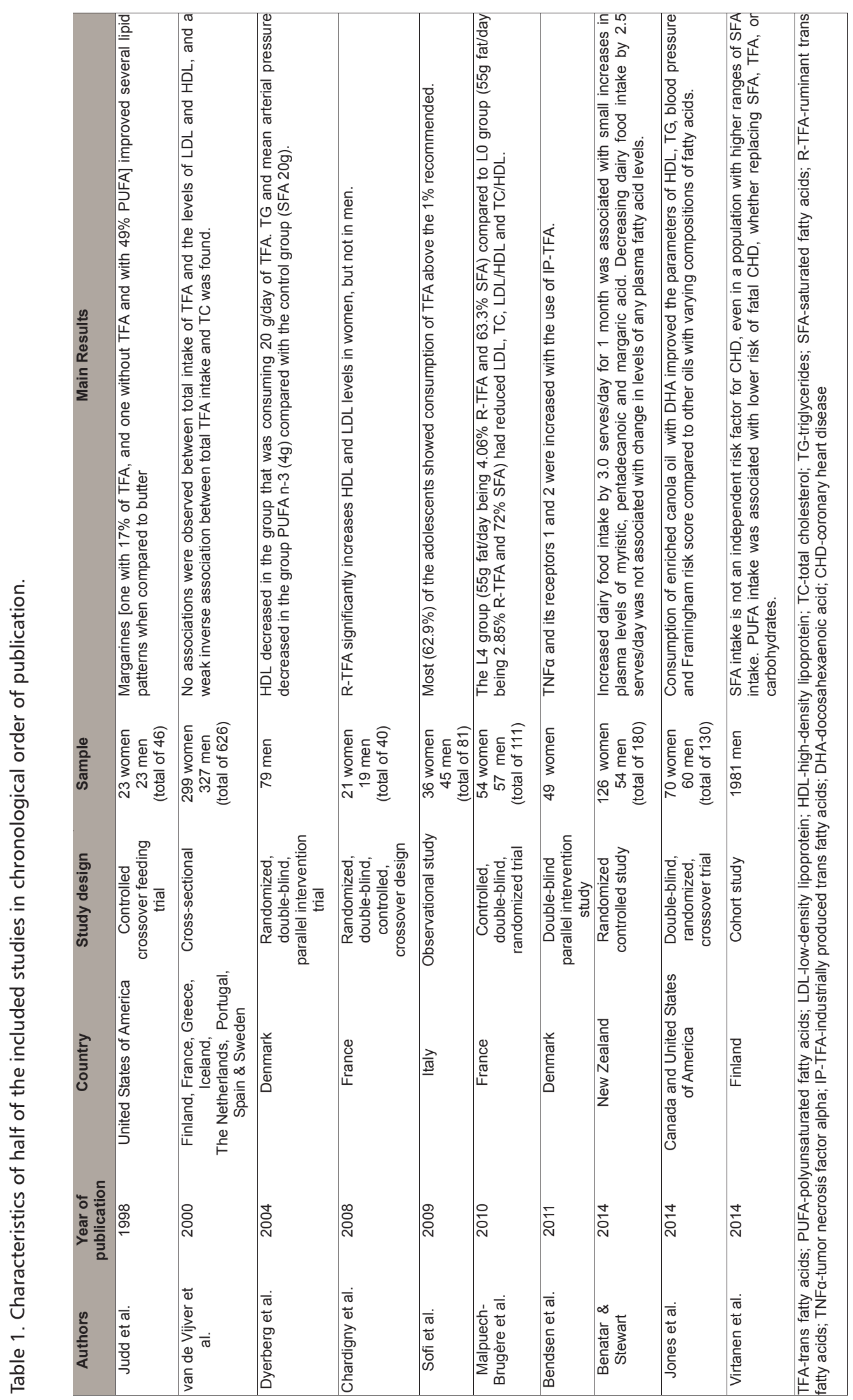


the Nurses' Health Study and Alpha-Tocopherol, Beta-Carotene Cancer Prevention Study no negative effects of R-TFA on relative risk of CHD were found, but IP-TFA was associated with increased risk of CHD (WILLETT et al., 1993; PIETINEN et al., 1997). In a review, a quantitative comparison of the effect of $\mathrm{R}$ -TFA, CLA (conjugated linoleic acid) and IP-TFA on blood lipids was described. All three TFA classes increased the LDL/HDL ratio and therefore could contribute to increased risk of CHD, R-TFA effect was weaker than the effects of IP-TFA but not significantly (BROUWER, WANDERS, KATAN, 2013). In another study, based on data from four Danish cohort studies, the R-TFA intake was not associated with increased risk of CHD (JAKOBSEN et al., 2008).

WHO has identified IP-TFA removal from the food supply as an intervention with favorable return on investment to reduce the economic impact of noncommunicable diseases in low and middle income countries (RUBINSTEIN et al., 2015). However, most of these countries have not yet included the restriction of IP-TFA intake as a policy. Governments have been concerned about the feasibility, achievability and public health effect of removing them from the food supply. The virtual complete elimination of TFA in countries such as Denmark, however, shows that reformulation is technically feasible. In fact, Denmark showed the largest decline in mortality from CHD in the European Union in the 1980-2009 period, and it is believed that the legislation has contributed to this trend (ALLEN et al., 2015).

Among the limitations of this review we can mention the fact that the reference lists of the analyzed articles and previous systematic and narrative reviews were not manually searched. In addition there were restrictions on language and databases, so the electronic search was not exhaustive.

\section{CONCLUSION}

Even if some variation of results between studies is observed, the general consensus is that TFA are considered a risk factor for general health. The literature on the effects of IP-TFA on health has been consistent with numerous studies suggesting that high doses of IP-TFA are associated with an increased risk of cardiovascular disease. Given the importance of eating habits on health, it is relevant to note that reducing the trans fat content of foods, through regulatory government intervention; and of the diet, through food selection, is only one component of a multifaceted strategy to improve nourishment and reduce the risk of chronic diseases related to diet, in particular cardiovascular diseases.

\section{REFERENCES}

ALLEN, K.; PEARSON-STUTTARD, J.; HOOTON, W.; DIGGLE, P.; CAPEWELL, S.; O'FLAHERTY, M. Potential of trans fats policies to reduce socioeconomic inequalities in mortality from coronary heart disease in England: cost effectiveness modelling study. BMJ, v. 351, p. h4583, 2015.

ASCHERIO, A.; HENNEKENS, C. H.; BURING, J. E.; MASTER, C.; STAMPFER, M. J.; WILLETT, W. C. Trans-fatty acids intake and risk of myocardial infarction. Circulation, v. 89, n. 1, p. 94-101, 1 jan. 1994.

AZAMBUJA, M. I. R.; FOPPA, M.; MARANHÃO, M. F. de C.; ACHUTTI, A. C. Economic burden of severe cardiovascular diseases in Brazil: an estimate based on secondary data. Arquivos Brasileiros de Cardiologia, v. 91, n. 3, p. 148155, 2008.

BENATAR, J. R.; STEWART, R. A. H. The effects of changing dairy intake on trans and saturated fatty acid levels - results from a randomized controlled study. Nutrition Journal, v. 13, n. 1, p. 32, 2014.

BENDSEN, N. T.; CHRISTENSEN, R.; BARTELS, E. M.; ASTRUP, A. Consumption of Industrial and Ruminant Trans Fatty Acids and Risk of Coronary Heart Disease: A Systematic Review and Meta-Analysis of Cohort Studies. European Journal of Clinical Nutrition, v. 65, n. 7, p. 773-83, 2011.

BENDSEN, N. T.; STENDER, S.; SZECSI, P. B.; PEDERSEN, S. B.; BASU, S.; HELLGREN, L. I.; NEWMAN, J. W.; LARSEN, T. M.; HAUGAARD, S. B.; ASTRUP, A. Effect of industrially produced trans fat on markers of systemic inflammation: evidence from a randomized trial in women. Journal of Lipid Research, v. 52, n. 10, p. 1821-1828, 2011.

BROUWER, I. A.; WANDERS, A. J.; KATAN, M. B. Trans fatty acids and cardiovascular health: research completed? European Journal of Clinical Nutrition, v. 67, n. 5, p. 541$547,2013$.

BROUWER, I. A.; WANDERS, A. J.; KATAN, M. B. Effect of animal and industrial trans fatty acids on HDL and LDL cholesterol levels in humans - A quantitative review. PLoS ONE, v. 5, n. 3, p. $1-10,2010$. 
CALDER, P. C. Functional Roles of Fatty Acids and Their Effects on Human Health. Journal of Parenteral and Enteral Nutrition, v. 39, n. 1_suppl, p. 18S-32, set. 2015

CHARDIGNY, J. M.; DESTAILLATS, F.; MALPUECH-BRUGÈRE, C.; MOULIN, J.; BAUMAN, D. E.; LOCK, A. L.; BARBANO, D. M.; MENSINK, R. P.; BEZELGUES, J. B.; CHAUMONT, P.; COMBE, N.; CRISTIANI, I.; JOFFRE, F.; GERMAN, J. B.; DIONISI, F.; BOIRIE, Y.; SÉBÉDIO, J. L. Do trans fatty acids from industrially produced sources and from natural sources have the same effect on cardiovascular disease risk factors in healthy subjects? Results of the trans Fatty Acids Collaboration (TRANSFACT) study. American Journal of Clinical Nutrition, v. 87, n. 3, p. 558-566, 2008.

CHOWDHURY, R.; JOHNSON, L.; STEUR, M. Trans fatty acid isomers in mortality and incident coronary heart disease risk. Journal of the American Heart Association, v. 3, n. 4, p. 1-5, 2014

CHOWDHURY, R.; WARNAKULA, S.; KUNUTSOR, S.; CROWE, F.; WARD, H. A.; JOHNSON, L.; FRANCO, O. H.; BUTTERWORTH, A. S.; FOROUHI, N. G.; THOMPSON, S. G.; KHAW, K.-T.; MOZAFFARIAN, D.; DANESH, J.; DI ANGELANTONIO, E. Association of Dietary, Circulating, and Supplement Fatty Acids With Coronary Risk A Systematic Review and Meta-analysis. Annals of Internal Medicine, v. 160 , n. 6, p. 398-406, 18 mar. 2014

DE SOUZA, R. J.; MENTE, A.; MAROLEANU, A.; COZMA, A. I.; HA, V.; KISHIBE, T.; ULERYK, E.; BUDYLOWSKI, P.; SCHÜNEMANN, H.; BEYENE, J.; ANAND, S. S. Intake of saturated and trans unsaturated fatty acids and risk of all cause mortality, cardiovascular disease, and type 2 diabetes: systematic review and meta-analysis of observational studies. BMJ, v. 351 , p. h3978, 2015.

DYERBERG, J.; ESKESEN, D. C.; ANDERSEN, P. W.; ASTRUP, a; BUEMANN, B.; CHRISTENSEN, J. H.; CLAUSEN, P.; RASMUSSEN, B. F.; SCHMIDT, E. B.; THOLSTRUP, T.; TOFT, E.; TOUBRO, S.; STENDER, S. Effects of trans- and n-3 unsaturated fatty acids on cardiovascular risk markers in healthy males. An 8 weeks dietary intervention study. European Journal of Clinical Nutrition, v. 58, n. 7, p. 1062-70, 2004.

FATTORE, E.; BOSETTI, C.; BRIGHENTI, F.; AGOSTONI, C.; FATTORE, G. Palm oil and blood lipid-related markers of cardiovascular disease: a systematic review and meta-analysis of dietary intervention trials. The American Journal of Clinical Nutrition, v. 99, n. 6, p. 1331-1350, 2014.

GAYET-BOYER, C.; TENENHAUS-AZIZA, F.; PRUNET, C.; MARMONIER, C.; MALPUECH-BRUGÈRE, C.; LAMARCHE, B.; CHARDIGNY, J.-M. Is there a linear relationship between the dose of ruminant trans-fatty acids and cardiovascular risk markers in healthy subjects: results from a systematic review and meta-regression of randomised clinical trials. British Journal of Nutrition, v. 112, n. 12, p. 1914-1922, 2014.
HARCOMBE, Z.; BAKER, J. S.; COOPER, S. M.; DAVIES, B.; SCULTHORPE, N.; DINICOLANTONIO, J. J.; GRACE, F. Evidence from randomised controlled trials did not support the introduction of dietary fat guidelines in 1977 and 1983: a systematic review and meta-analysis. Open Heart, v. 2, p. e000196, 2015.

JAKOBSEN, M. U.; OVERVAD, K.; DYERBERG, J.; HEITMANN B. L. Intake of ruminant trans fatty acids and risk of coronary heart disease. International Journal of Epidemiology, v. 37, n. 1, p. 173-182, 1 fev. 2008.

JAVAHERI, A.; RADER, D. J. Apolipoprotein A-I and cholesterol efflux: The good, the bad, and the modified. Circulation Research, v. 114, p. 1681-1683, 2014.

JONES, P. J. H.; SENANAYAKE, V. K.; PU, S.; JENKINS, D. J. A.; CONNELLY, P. W.; BARIL-GRAVEL, L.; WEST, S. G.; LIU, X.; FLEMING, J. A.; COUTURE, P.; MCCREA, C. E.; KRIS-ETHERTON, P. M. DHA-enriched high - oleic acid canola oil improves lipid profile and lowers predicted cardiovascular disease risk in the canola oil multicenter randomized controlled trial. American Journal of Clinical Nutrition, v. 100, p. 88-97, 2014.

JUDD, J. T.; BAER, D. J.; CLEVIDENCE, B. A.; MUESING, R. A.; CHEN, S. C.; WESTSTRATE, J. A.; MEIJER, G. W.; WITTES, J.; LICHTENSTEIN, A. H.; VILELLA-BACH, M.; SCHAEFER, E. J. Effects of margarine compared with those of butter on blood lipid profiles related to cardiovascular disease risk factors in normolipemic adults fed controlled diets. American Journal of Clinical Nutrition, v. 68, n. 4, p. 768-777, 1998.

KIAGE, J. N.; MERRILL, P. D.; JUDD, S. E.; HE, K.; LIPWORTH L.; CUSHMAN, M.; HOWARD, V. J.; KABAGAMBE, E. K. Intake of trans fat and incidence of stroke in the REasons for Geographic and Racial Differences in Stroke (REGARDS) cohort. American Journal of Clinical Nutrition, v. 99, n. 5, p. 1071-1076, 2014.

LAAKE, I.; PEDERSEN, J. I.; SELMER, R.; KIRKHUS, B.; LINDMAN, A. S.; TVERDAL, A.; VEIEROD, M. B. A prospective study of intake of trans-fatty acids from ruminant fat, partially hydrogenated vegetable oils, and marine oils and mortality from CVD. The British Journal of Nutrition, v. 108, n. 4, p. 743-754, 2012.

MALPUECH-BRUGÈRE, C.; MOURIOT, J.; BOUE-VAYSSE, C.; COMBE, N.; PEYRAUD, J.-L.; LERUYET, P.; CHESNEAU, G.; MORIO, B.; CHARDIGNY, J.-M. Differential impact of milk fatty acid profiles on cardiovascular risk biomarkers in healthy men and women. European Journal of Clinical Nutrition, v. 64, n. 7, p. 752-759, 2010.

MARTIN, C. A.; MILINSK, M. C.; VISENTAINER, J. V; MATSUSHITA, M.; DE-SOUZA, N. E. Trans fatty acid-forming processes in foods: A review. Anais da Academia Brasileira de Ciências, v. 79, n. 2, p. 343-350, 2007. 
MENSINK, R. P.; KATAN, M. B. Effect of a Diet Enriched with Monounsaturated or Polyunsaturated Fatty Acids on Levels of Low-Density and High-Density Lipoprotein Cholesterol in Healthy Women and Men. The New England Journal of Medicine, v. 321, n. 7, p. 436-441, 1989.

MENSINK, R. P.; KATAN, M. B. Effect of Dietary Trans Fatty Acids on High-Density and Low-Density Lipoprotein Cholesterol Levels in Healthy Subjects. The New England Journal of Medicine, v. 323, n. 7, p. 439-445, 1990.

MENSINK, R. P.; KATAN, M. B. Trans Monounsaturated Fatty Acids in Nutrition and Their Impact on Serum Lipoprotein Levels in Man. Progress in Lipid Research, v. 32, n. 1, p. 111-122, 1993.

MENSINK, R. P.; TEMME, E. H.; HORNSTRA, G. Dietary Saturated and Trans Fatty Acids and Lipoprotein Metabolism. Annals of Medicine, v. 26, n. 6, p. 461-464, 1994.

MICHA, R.; MOZAFFARIAN, D. Trans Fatty Acids: Effects on Metabolic Syndrome, Heart Disease and Diabetes. Nature Reviews Endocrinology, v. 5, n. 6, p. 335-344, 2009.

MOZAFFARIAN, D.; ARO, A.; WILLETT, W. C. Health effects of trans-fatty acids: experimental and observational evidence. European Journal of Clinical Nutrition, v. 63 Suppl 2, n. S2, p. S5S2I, 2009.

MOZAFFARIAN, D.; CLARKE, R. Quantitative effects on cardiovascular risk factors and coronary heart disease risk of replacing partially hydrogenated vegetable oils with other fats and oils. European Journal of Clinical Nutrition, v. 63 Suppl 2, n. S2, p. S22-S33, 2009.

MOZAFFARIAN, D.; KATAN, M. B.; ASCHERIO, A.; STAMPFER, M. J.; WILLETT, W. C. Trans Fatty Acids and Cardiovascular Disease. New England Journal of Medicine, v. 354, n. 15, p. 1601-1613, 2006.

MOZAFFARIAN, D.; PISCHON, T.; HANKINSON, S. E.; RIFAI, N.; JOSHIPURA, K.; WILLETT, W. C.; RIMM, E. B. Dietary Intake of Trans Fatty Acids and Systemic Inflammation in Women. The American Journal of Clinical Nutrition, v. 79, n. 4, p. 606-612, 2004.

MOZAFFARIAN, D.; RIMM, E. B.; KING, I. B.; LAWLER, R. L.; MCDONALD, G. B.; LEVY, W. C. Trans Fatty Acids and Systemic Inflammation in Heart Failure. The American Journal of Clinical Nutrition, v. 80, n. 6, p. 1521-5, 2004.

MUNIZ, L. C.; SCHNEIDER, B. C.; SILVA, I. C. M. Da; MATIJASEVICH, A.; SANTOS, I. S. Fatores de risco comportamentais acumulados para doenças cardiovasculares no sul do Brasil. Revista de Saúde Pública, v. 46, n. 3, p. 534-542, 2012.

NISHIDA, C.; UAUY, R. WHO Scientific Update on health consequences of trans fatty acids: introduction. European
Journal of Clinical Nutrition, v. 63 Suppl 2, n. S2, p. S1-S4 2009.

PEREIRA, R. A; DUFFEY, K. J.; SICHIERI, R.; POPKIN, B. M. Sources of excessive saturated fat, trans fat and sugar consumption in Brazil: an analysis of the first Brazilian nationwide individual dietary survey. Public Health Nutrition, v. 17 , n. 1, p. 113-21, 2014.

PIETINEN, P.; ASCHERIO, A; KORHONEN, P.; HARTMAN, a M.; WILLETT, W. C.; ALBANES, D.; VIRTAMO, J. Intake of fatty acids and risk of coronary heart disease in a cohort of Finnish men. The Alpha-Tocopherol, Beta-Carotene Cancer Prevention Study. American Journal of Epidemiology, v. 145, n. 10, p. $876-887,1997$.

RUBINSTEIN, A.; ELORRIAGA, N.; GARAY, O. U.; POGGIO, R.; CAPORALE, J.; MATTA, M. G.; AUGUSTOVSKI, F.; PICHON-RIVIERE, A.; MOZAFFARIAN, D. Eliminating artificial trans fatty acids in Argentina: estimated effects on the burden of coronary heart disease and costs. Bulletin of the World Health Organization, v. 93, n. 9, p. 614-622, 2015.

SACKS, F. M.; KATAN, M. Randomized clinical trials on the effects of dietary fat and carbohydrate on plasma lipoproteins and cardiovascular disease. American Journal of Medicine, v. 113, n. 9 SUPPL. 2, p. 13S-24S, 2002.

SALTER, A. M. Dietary fatty acids and cardiovascular disease. Animal, v. 7 Suppl 1, p. 163-171, 2011.

SIRI-TARINO, P. W.; SUN, Q.; HU, F. B.; KRAUSS, R. M. Saturated fat, carbohydrate, and cardiovascular disease. American Journal of Clinical Nutrition, n. 5, p. 502-509, 2010.

SKEAFF, C. M.; MILLER, J. Dietary Fat and Coronary Heart Disease: Summary of Evidence from Prospective Cohort and Randomised Controlled Trials. Annals of Nutrition and Metabolism, v. 55, n. 1-3, p. 173-201, 2009.

SOFI, F.; RAPINI, D.; INNOCENTI, G.; ABBATE, R.; GENSINI, G. F.; CASINI, A. Dietary intake of trans fatty acids as a cardiovascular risk factor in a population of Italian teenagers. Cardiology in the Young, v. 19, p. 589-593, 2009.

STENDER, S.; ASTRUP, A.; DYERBERG, J. Ruminant and industrially produced trans fatty acids: Health aspects. Food and Nutrition Research, v. 52, p. 1-8, 2008.

SUNDRAM, K.; ISMAIL, A.; HAYES, K. C.; JEYAMALAR, R.; PATHMANATHAN, R. Trans (Elaidic) Fatty Acids Adversely Affect the Lipoprotein Profile Relative to Specific Saturated Fatty Acids in Humans. The Journal of Nutrition, v. 127, n. 3, p. 514S-520S, 1997.

TAVANI, A; NEGRI, E.; D'AVANZO, B.; LA VECCHIA, C. Margarine intake and risk of nonfatal acute myocardial infarc- 
tion in Italian women. European Journal of Clinical Nutrition, v. 51, p. 30-32, 1997.

TEICH, V.; ARAUJO, D. V. Estimativa de Custo da Síndrome Coronariana Aguda no Brasil. RevisTa Brasileira de Cardiologia, v. 24, n. 2, p. 85-94, 2011.

TRATTNER, S.; BECKER, W.; WRETLING, S.; ÖHRVIK, V.; MATTISSON, I. Fatty acid composition of Swedish bakery products, with emphasis on trans-fatty acids. Food Chemistry, v. 175, p. $423-430,2015$.

VAN DE VIJVER, L. P. L.; KARDINAAL, A. F. M.; COUET, C.; ARO, A.; KAFATOS, A.; STEINGRIMSDOTTIR, L.; AMORIM CRUZ, J. A.; MOREIRAS, O.; BECKER, W.; VAN AMELSVOORT, J. M. M.; VIDAL-JESSEL, S.; SALMINEN, I.; MOSCHANDREAS, J.; SIGFÚSSON, N.; MARTINS, I.; CARBAJAL, A.; YTTERFORS, A.; VAN POPPEL, G. Association between trans fatty acid intake and cardiovascular risk factors in Europe: the TRANS FAIR study. European Journal of Clinical Nutrition, v. 54, n. 2 , p. $126-135,2000$.

VIRTANEN, J. K.; MURSU, J.; TUOMAINEN, T.-P.; VOUTILAINEN, S. Dietary Fatty Acids and Risk of Coronary Heart Disease in Men: The Kuopio Ischemic Heart Disease Risk Factor Study. Arteriosclerosis, Thrombosis, and Vascular Biology, v. 34, n. 12 , p. 2679-87, 2014.

WANG, Q.; IMAMURA, F.; LEMAITRE, R. N.; RIMM, E. B.; WANG, M.; KING, I. B.; SONG, X.; SISCOVICK, D.; MOZAFFARIAN, D. Plasma Phospholipid Trans-Fatty Acids Levels, Car- diovascular Diseases, and Total Mortality: The Cardiovascular Health Study. Journal of the American Heart Association, v. 3114, 2014

WANG, Y.; JACOME-SOSA, M. M.; PROCTOR, S. D. The role of ruminant trans fat as a potential nutraceutical in the prevention of cardiovascular disease. Food Research International, v. 46, n. 2, p. 460-468, 2012.

WILLETT, W. C. Trans Fatty Acids and Cardiovascular Disease-Epidemiological Data. Atherosclerosis Supplements, v. 7, n. 2, p. 5-8, 2006.

WILLETT, W. C.; STAMPFER, M. J.; MANSON, J. E.; COLDITZ, G. A.; SPEIZER, F. E.; ROSNER, B. A.; HENNEKENS, C. H.; HENNEKENS, C. H.; WILLETT, W. C.; STAMPFER, M. J.; COLDITZ, G. A.; WILLETT, W. C.; SAMPSON, L. A.; ROSNER, B. A. Intake of trans fatty acids and risk of coronary heart disease among women. The Lancet, v. 341, n. 8845, p. 581-585, 1993.

WILLETT, W. C. Dietary fats and coronary heart disease. Journal of Internal Medicine, v. 272, n. 1, p. 13-24, 2012.

WORLD HEALTH ORGANIZATION. European Food and Nutrition Action Plan 2015 - 2020. v. 5, p. 24, 2015.

WORLD HEALTH ORGANIZATION. Fats and fatty acids in human nutrition. Report of an expert consultation. v. 91, p.180, 2008 